\title{
Teaching Approach of Theory-Centered Course for Freshmen of Business English Major: A Case Study of "Research Methodology" Course
}

\author{
Yue Siwei ${ }^{1} \&$ Wang Xuefei ${ }^{2}$ \\ ${ }^{1}$ School of English for International Business, Guangdong University of Foreign Studies, Guangzhou, China \\ ${ }^{2}$ School of Applied English, The Open University of Guangdong, Guangzhou, China \\ Correspondence: Wang Xuefei, School of Applied English, The Open University of Guangdong, Guangzhou, \\ 510091, China.
}

Received: January 8, 2019 Accepted: February 16, 2019 Online Published: February 18, 2019

doi: 10.5539/elt.v12n3p191 URL: https://doi.org/10.5539/elt.v12n3p191

\begin{abstract}
This study explores the teaching approach of the general courses of theoretical knowledge targeted at the freshmen based on a pilot study of the course Research Methodology in School of English for International Business (SEIB) in Guangdong University of Foreign Studies. A questionnaire survey of 163 freshmen who take the course at two consecutive terms indicates that the course is pedantic and lectures' inputs are invariable and the teacher participation is insufficient. After implementing a teaching reform against these defects, the methods of adopting case study and improving teacher participation meet the expectation of students in spite that the teacher participation is over-performed. Meanwhile, the pedantic attribute of the course remains even with an attempt to diversify the lecture inputs and to reduce the ratio of English to Chinese as the working language in lectures. This study suggests that the general courses of theoretical knowledge should be put off to the second year of university. Flipped classroom philosophy is recommended where the pre-class preparation is enforced and the teacher performs as a learning assistant for the students when executing research projects.
\end{abstract}

Keywords: teaching approach, general course of theoretical knowledge, research methodology, business English major

\section{Introduction}

Considering the fact that the preliminary theoretical course is the foundation and guideline for the acquiring of specialized courses, an increasing number of Business English schools in China begin to add theory-centered preliminary courses to freshmen's curriculum. However, the theory-centered courses' pedantic and abstract quality frequently dissatisfies freshmen in every aspect. An interesting and efficient teaching methodology tailored to theory-centered preliminary courses of Business English Majored freshmen is in urgent need. Some scholars have discussed the roles teachers should play in the classroom and their relation with students. Liu Fagong (2015) proposes four notions of teaching, three of which emphasizes the decisive role the teacher plays in teaching reform. He believes that teaching methods need to be innovated. The teacher and student should establish a dynamic and cooperative relation in classroom. Others examine the components of Business English teachers' capabilities (Wang \& Zhang, 2011), both of which haven't yet touched upon the concrete teaching procedures. Present research (Xie \& Peng, 2009; Wang \& Duan, 2010; Jia, 2016; Jiang, 2011) about teaching methodology of Business English courses concentrates on application of mainstream Business English teaching methods: discussion, situational teaching and case teaching method to specialized courses. Jiang Huaying (2011) discussed the feasibility and necessity of applying the task-oriented method. Chu Hongyan and Cong Qiaohua (2017) argued how information technology should be implemented to improve teaching and learning in classroom. In general, the current studies on the teaching methodology of Business English courses all encourage students' autonomy in learning and teachers' practical teaching methods. However, these studies either consider the curriculum of Business English major as a whole, or narrow down to a particular type of specialized course which mentions little about the teaching methodology of theory-centered preliminary courses. Therefore, this study focuses on the specific type of course--theory-centered preliminary course of Business English majors, carrying out a case study of the course "Research Methodology" targeting at freshmen in School of English for 
International Business (SEIB) in Guangdong University of Foreign Studies. Three research questions are proposed in this study. Question 1: What are the teaching problems of Research Methodology course before teaching reform? Question 2: What are the effects of the teaching reform of Research Methodology course? Question 3: What measures can be taken to improve the teaching quality of the general courses of theoretical knowledge targeted at the freshmen? To answer them, this study carried out an empirical study in hopes that the results can inspire more research on teaching methodology of theory-centered preliminary course of Business English major.

\section{Research Methodology}

\subsection{Research Design}

This study devises three steps to explore the teaching reform's effects. At the first step, a questionnaire survey is carried out at the end of the first term among students who take Research Methodology course without implementing any reformative operation. Based on their evaluation and feedback about the teaching problems of this course, this study tentatively proposes some innovative teaching approaches that are about to be executed in the second term's reformative lectures. At the second step, when students finish all the lectures of the reformed course over the term, the second questionnaire survey is distributed and their feedback is obtained for later comparison so as to detect the effectiveness of the reform. The third step is designated for the discussion of effectiveness of the teaching approaches adopted in this reform, on which the proposal of several suggestions is based.

\subsection{Data Collection}

At the first phase, this study chooses 163 participants from School of English for International Business (SEIB) in Guangdong University of Foreign Studies, Guangzhou, China to attend a questionnaire survey. They are freshmen who just finish their "Research Methodology" course. Questionnaire 1has 12 multiple-choice questions (question 1-12) and 4 open-ended questions (question 13-16), which concentrates on the problems of current teaching approaches.

At the second phase when the teaching reform is implemented, 80 participants who take reformed "Research Methodology" course are invited to answer another questionnaire for the examination of the effectiveness of the reform. Questionnaire 2 has 34 multiple-choice questions which focus on the participants' response to the effectiveness of various practices to implement new teaching approaches. Both questionnaires are disseminated and withdrawn through "Star"-an online survey platform mediated by social networking application Wechat. The main concern of this survey is (1) whether students' satisfaction with this course has been improved after the improvement of teaching approaches of this course? Do they effectively acquire knowledge about research methods through the teaching? (2) How can teaching approaches be improved to make the class more efficient? What valuable comments do students make on the course?

\subsection{Data Analysis}

As for the analysis of questionnaire 1, the author calculates the ratio of the various factors contributing to the inefficiency of the students' performance in the course. By targeting at keywords of open-ended questions, the study depicts how each factor is manifested in classroom practices in detail. Questionnaire 2 is analyzed in contrast to the results of questionnaire 1. On the basis of similar keywords, satisfaction and performance were analyzed in sequence where qualitative and quantitative studies are used to detect students' acceptance degree, satisfaction degree and improvement suggestions for teaching content.

\section{Results and Discussion}

\subsection{Problems of this Course Before Reform}

Research Methodology course, as one of the theory-oriented course for business English majors, aims to guide students through the research process for a business research project such as how to design the research plan, choose appropriate research tools and methods, carry out the research and write a research report. This course is set as a compulsory course for freshmen and is mainly taught in English. The course lasts for one term with one lecture (80 minutes) per week. Apart from one reference book, the learning materials are handouts mainly provided by the teacher, such as courseware and suggested literature. The assessment is based on the completion of group work of research project and theory tests of final exam paper. The project is supposed to be orally and literally presented at the end of the course.

Questionnaire survey of phase 1 is implemented for the account of extracting the defects of current teaching approach. By analyzing the feedback from questionnaire 1, this study pinpoints several factors that account for 
students' in-class low efficiency. The data drawn from the multiple-choice questions how that the difficulty of the content by itself $(40.40 \%)$, uninteresting teaching approaches $(23.07 \%)$, the abstract instruction $(18.87 \%)$, and insufficient feedback $(12.59 \%)$ are the main causes that result in the low efficiency of students' academic performance, regardless of students' internal motivation .

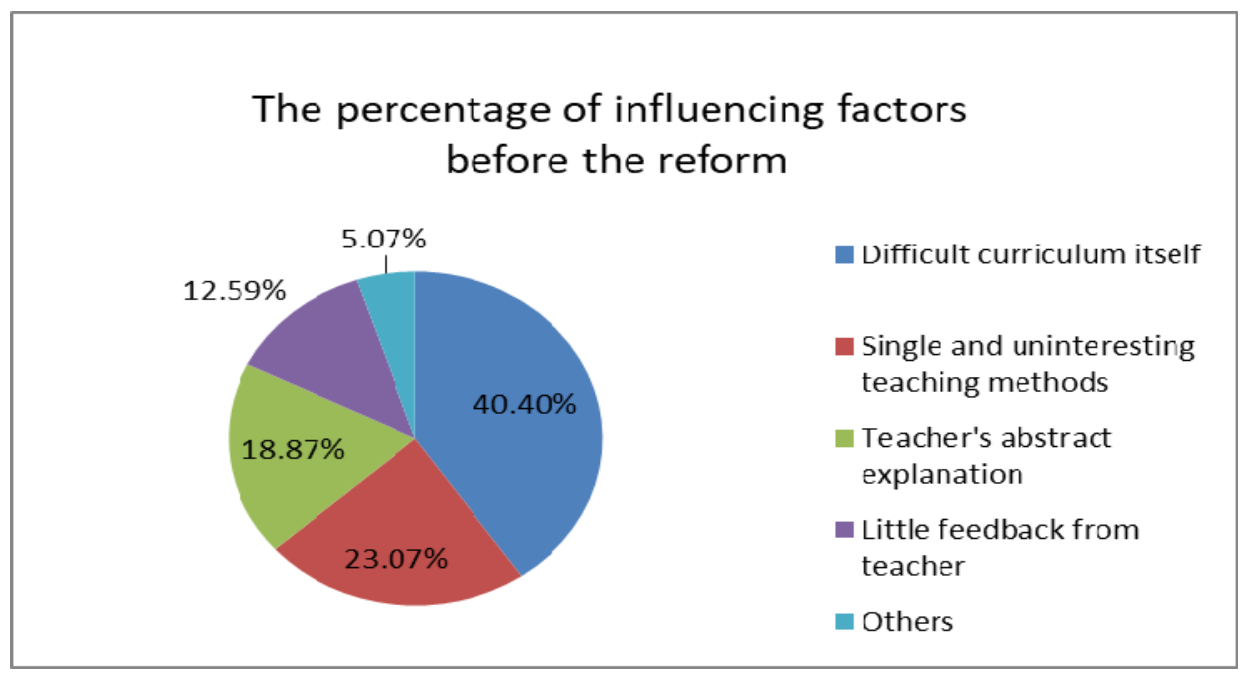

Figure 1. The Percentage of Influencing Factors before the reform

In addition, the answers of open-ended questions (question 13-16) provide more details about how each factor leads to the negative performance of the teaching and learning of the course.

Table 1. Influencing factors and their specific performances

\begin{tabular}{lll}
\hline Potential Factors & Proportion & Specific performance \\
\hline Difficult content & $40.40 \%$ & $\begin{array}{l}\text { The content itself covers a wide range of unintelligible theoretical } \\
\text { knowledge }\end{array}$ \\
$\begin{array}{l}\text { Pedantic and } \\
\text { monotonous } \\
\text { teaching approaches }\end{array}$ & $23.07 \%$ & $\begin{array}{l}\text { In most cases, only Powerpoint slides are used in teaching. Video } \\
\text { presentation and other instructional media are occasionally used in class. }\end{array}$ \\
$\begin{array}{l}\text { Teacher's abstract } \\
\text { instruction }\end{array}$ & $18.87 \%$ & $\begin{array}{l}\text { As for the instructive language, the ratio of English to Chinese is } 8: 2 . \\
\text { Teaching of theoretical contents took up the majority, which lacks case } \\
\text { analysis and discussion }\end{array}$ \\
$\begin{array}{l}\text { Insufficient } \\
\text { feedback from the } \\
\text { teacher }\end{array}$ & $12.59 \%$ & $\begin{array}{l}\text { In general, there is no fixed time for students to ask the teacher about their } \\
\text { doubts. Occasionally, the group leader collects doubts from other members } \\
\text { and present to the teacher. No social networking app or e-mails are used to } \\
\text { answer questions and give feedback after class. }\end{array}$ \\
Others & $5.07 \%$ &
\end{tabular}

Students generally believe that the problems concerning teaching approach are: An insufficient task instruction; B. unintelligible working language; C. monotonous teaching approach. Besides, there are two aspects linked to the curricular setting and course design: A. difficulty of content from the perspective of freshmen (especially in the field of self-designed research); B. Insufficient teaching materials; C. Lack of chances for research practices.

In open-ended questionnaire 14, the students put forward four suggestions: 1) The teaching method should be more diversified 2) the teacher should provide more supplementary references 3) the lecture should carry out more case studies 4 ) the teacher should provide more after-school guidance. 


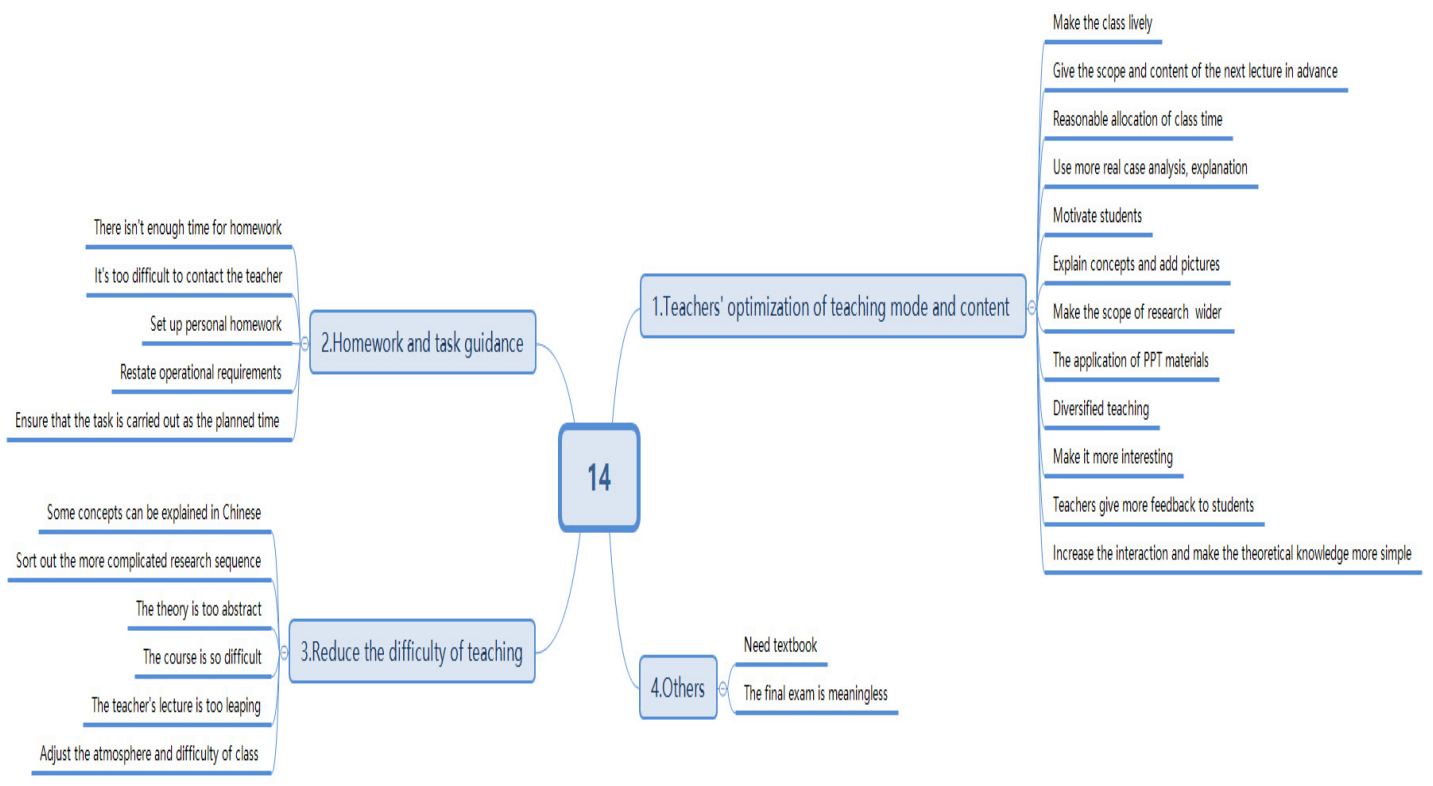

Question 14. what are your suggestions for the teacher of this course?

Figure 2. Suggestions for the teacher

Apart from students' subjective factors such as low learning motivation, the obscure and pedantic attributes of all theory-oriented general courses make the teaching of these courses a challenge, especially when the students are freshmen who have little experience or related knowledge. In this case, the teacher's insufficient after-class guidance as well as the monotonous teaching approach adds to the learning difficulty. The Research Methodologies a theory-oriented course which has few practice opportunities in class. Consequently, a student who never has any knowledge or experience about research generally thinks that such a course is too difficult to learn, and his learning interest therefore drastically drops.

As for the teaching plan design, out of the good will that students should be empowered to have creative ideas and fully participate in every step throughout the whole project, the teacher let students search for research subjects, work out research questions and design research plan on their own along with the proceeding of lectures. But she ignores the fact that students who bear little experience and knowledge cannot generate any feasible ideas even under the guidance of lectures. In terms of teaching approach, there is no demonstrative analysis, and the class discussion time is insufficient. Under such circumstances, the students are confused most of the time both in lectures and in after-class project operation.

The problems of this course before reform mainly lie in four aspects: the content; the teacher's guidance and feedback to students' research projects; the teaching approaches in class and lastly teaching materials. Based on the survey's results, an experiment is carried out at the second phase where some measures are taken to improve the conduct concerning the four aspects.

\subsection{The Implementation of Reform and Its Effects}

\subsubsection{The Implementation of Reform}

Based on Questionnaire 1's suggestions, the teacher makes some changes to the teaching of the next term, which is elaborated in the table below.

Table 2. The comparison of teaching arrangements between before and after reform

\begin{tabular}{llll}
\hline & Aspects & Before reform & After reform \\
\hline $\begin{array}{l}\text { Before } \\
\text { class }\end{array}$ & Preview task & None & $\begin{array}{l}\text { Assign reading task concerning next } \\
\text { lecture(textbook, literature, manual of } \\
\text { software) }\end{array}$ \\
\hline
\end{tabular}


Project design $\quad$ By Self

Teaching material content and

Mainly textbook, powerpoint slides

Teaching approach

\section{In class}

Interaction

Theoretical knowledge teaching

Working language

Assignments

Supervision of group work None allocation

Instruction of project discussion with the teacher at the interval students have a face to face

The teacher's lecturing takes the most time; case study is occasionally carried out with group discussion but the group discussion time is flexible

Groups are given more than 20 minutes for the project discussion in a random manner

Takes the most time of class

20\%Chinese VS. 80\% English

The assignments self-determined according to students' own schedule of executing the project plan

$\begin{array}{ll}\begin{array}{l}\text { After } \\ \text { class }\end{array} & \begin{array}{l}\text { Supervision of } \\ \text { group work None } \\ \text { allocation }\end{array} \\ & \begin{array}{l}\text { Instruction of } \\ \text { project }\end{array}\end{array}$

\section{By the teacher}

The tutoring of project outweighs the textbook lectures; textbook contents are partly selected for lectures based on their relevance to the group's project; video clips are used more often.

The number of case studies increase and the cases chosen are more relevant to the project; group discussion is a routine activity.

Group discussion time is reduced to 10 minutes in a routine manner

Takes less than half the time of class

\section{0\%Chinese VS. 50\% English}

The teacher gives specific instructions in the first four weeks, later each group set tasks according to their own schedule.

Group leaders are asked to fill up a worksheet to specify each member's contribution to the completion of group work.

The teacher builds up online discussion groups through social networking apps where students ask questions and receive instructions from the teacher.

The teaching reform is executed to meet the needs of former students, who suggest teaching methods should be more diversified; extracurricular reference materials should be added; there should be more case analysis and more after-school guidance.

The teacher has provided the guidance before, during and after class to help students better understand the knowledge related to this course. The teacher has also offered more assistances in project design and team work to supervise students to complete the research project better. In addition, the teacher has increased the number of more practical cases related to the curriculum and provided more reference materials for the students. With more cases and information, the knowledge of the subject is easier to be understood by the students.

Apart from the improvements, teacher retains good aspects she has done before, such as the guidance of the structure of thesis writing. The inadequacies that students put forward are revised, such as adding class discussion time, adding cases, giving guidance to the research topics, answering questions on line and offline. However, some of the suggestions have not been modified for some limitations. For example, the previous students think that the way of teaching is relatively monotonous and they hope that the PPT form can be more diversified, at the same time more video and pictures can be added to increase interest, but these requirements have not been met.

\subsubsection{The Effects of Reform}

Before the reform, $20 \%$ of students thought the course was difficult and should be set up in a higher grade. The majority of students thought that teachers' teaching methods should be improved, such as increasing the analysis of practical cases, improving the presentation of classroom contents, and giving more homework and task 
guidance to students.

After the teacher made adjustments responding to the four aspects, the author distributes a new questionnaire (questionnaire 2) among the current students and got the following data (Figure). According to the statistics of this questionnaire, students' complaints in the four aspects have been mitigated in general.

As Table 3 suggests, former students' complaints about the four aspects have been addressed by activities before, during and after class.

Table 3. The effects of reform

\begin{tabular}{|c|c|c|}
\hline Student's feedback & Reform of teaching method & change \\
\hline & $\begin{array}{l}\text { Before class: add some reading material that student might use } \\
\text { in the next class. }\end{array}$ & \\
\hline \multirow{2}{*}{ The course is difficult } & $\begin{array}{l}\text { During class: the ratio of Chinese and English has been adjusted } \\
\text { from 2:8 to 5:5. }\end{array}$ & \multirow{2}{*}{$2.62 \%$} \\
\hline & $\begin{array}{l}\text { After class: Give student specific instructions at the first four } \\
\text { week. }\end{array}$ & \\
\hline $\begin{array}{l}\text { The teaching method is unitary and } \\
\text { not very interesting }\end{array}$ & $\begin{array}{l}\text { During class: Video shows increased, theoretical lectures } \\
\text { decreased, and group discussions become a routine activity. }\end{array}$ & $3.51 \%$ \\
\hline $\begin{array}{l}\text { Teacher's explanation is abstract } \\
\text { and difficult to understand }\end{array}$ & $\begin{array}{l}\text { During class: Teaching materials decreased, theory decreased, } \\
\text { case analysis increased. }\end{array}$ & $8 \%$ \\
\hline $\begin{array}{l}\text { Teacher gives little feedback to } \\
\text { students }\end{array}$ & $\begin{array}{l}\text { During class: Answer questions for the first } 20 \text { minutes of a } \\
\text { class, } \\
\text { After class: answer student's questions through the WeChat. }\end{array}$ & $5.92 \%$ \\
\hline
\end{tabular}

The effects of reform in the 4 aspects are uneven. The improvement on "the course is difficult" only accounts for $2.62 \%$. The change is very small, given that the quality of students themselves has large influence on this aspect. As a theory-oriented course for business English majors, the content is abstract by nature. Therefore, it is not sensible to set such a course for freshmen. The indirect experience of general knowledge theory course is relatively large, so students cannot find the most practical knowledge and methods that can be applied to the theory. Meanwhile, theoretical courses may lead to monotonous teaching organization and instructional teaching methods, which make it difficult to fully motivate the activeness students.

As for the complaint of "the teaching method is unitary and not very interesting", the number has decreased by $3.51 \%$. The reform of teaching approaches such as fixing the discussion time, increasing case study and video clip demonstration contribute greatly to the proliferation of students' interest in lectures. Based on the questionnaire survey, the routine in-class discussion is favored by most students. $86.25 \%$ of the students think it's necessary and effective, which meets their needs. (see Table 4)

Table 4. (Multiple choice): Do you think the class discussion time arranged by the teacher is useful?

\begin{tabular}{llc}
\hline Options & Subtotal & Proportion \\
\hline $\begin{array}{l}\text { Useful, let the students organize the research process while } \\
\text { getting the teacher's guidance }\end{array}$ & 69 & $86.25 \%$ \\
$\begin{array}{l}\text { It doesn't make much difference. We seldom come to any } \\
\text { meaningful conclusions }\end{array}$ & 8 & $10 \%$ \\
Nothing, all right & 3 & $3.75 \%$ \\
\hline
\end{tabular}

In terms of "teacher's explanation is abstract and difficult to understand", the number has decreased by $8 \%$.Before the reform, "Teacher's abstract explanation" is one of the factors that influence students' participation in curriculum behavior. Based on the chart, this factor takes 18.87 percent. In view of this phenomenon, the teacher spends less time on explain difficult theoretical textbook in the course, increases the analysis of the 
actual cases related to this professional knowledge, and guides the students to understand the research steps and processes from the simple to the deep. The percentage of factors that "Teacher's abstract explanation" is only 10.87 percent, down by eight percentage points. The reform of this teaching method is the most effective and remarkable. In order to make the tutoring of the project more intelligible, the teacher offers the research topic to each group and provides some help in formulating a research plan. This trial wins the majority's favor (95\%). But $38.75 \%$ of them believe it is also advisable for teachers to give directions and let students determine the research topic themselves. (see Table 5).

Table 5. (Multiple choice): Do you think it's a good idea for teacher to determine the subject?

\begin{tabular}{lll}
\hline Options & Subtotal & Proportion \\
\hline Good, it saves students' time to draw up their own project & 45 & $56.25 \%$ \\
$\begin{array}{l}\text { Either way, I hope the teacher can give the direction on the } \\
\text { topic selection and let the students decide the research topic } \\
\text { themselves }\end{array}$ & $38.75 \%$ \\
$\begin{array}{l}\text { Not good, the topic set by the teacher is too difficult, which } \\
\text { beyond our ability as freshmen }\end{array}$ & 4 & $5 \%$ \\
\hline
\end{tabular}

In terms of learning status, $75 \%(6.25 \%+68.75 \%)$ of students have a good or full understanding of the knowledge in class, but $3.75 \%$ of them still have a poor attitude towards this course and have a low acceptance. (see Table 6).

Table 6. (Multiple choice): How are you getting on your research method course atpresent?

\begin{tabular}{lll}
\hline Options & Subtotal & Proportion \\
\hline I could understand every knowledge in class & 5 & $6.25 \%$ \\
I could understand most of the knowledge in class & 55 & $68.75 \%$ \\
I tried my best, but couldn't understand either & 17 & $21.25 \%$ \\
I listened carefully for a while, only to find it was too hard to & 2 & $2.5 \%$ \\
understand & 1 & $1.25 \%$ \\
I didn't listen at all, because I didn't want to & & \\
\hline
\end{tabular}

In terms of "Teacher gives little feedback to students", before the reform, "Little feedback from teacher" is another factor affecting students' curriculum participation in behaviour, accounting for $12.59 \%$. In view of this phenomenon, the teacher increases the feedback to students and let the student and the team member communicate the research process and answer the questions for the students in the 10 minutes before class. After class, the teacher communicates with the student through WeChat online and gives the feedback and answers the questions in time. After the reform, the percentage of teacher feedback decrease to $6.67 \%$, and the effect of the reform is obvious.

By comparison, the study indicates that students' satisfaction has prominently increased in terms of the teacher's instruction and feedback to students' project execution by implementing following teaching approaches.

1). Adopt case study and video clip demonstration

2). Set 10 minutes in the beginning of every class for a group discussion to answer students' questions and give feedback.

3). Use social networking application WeChat to instruct students' project execution after class.

\subsubsection{The deficiency of the Reform}

Meanwhile, it is also notable that not every measure taken in the reform is effective according to students' feedback in the questionnaire.

The previous collection of students' opinion towards the course indicates that the depth and difficulties of the course is one of the most significant contributory causes of the little students' participation in class. Thus, 
adjusting measures includes allocating reading tasks before class, increasing the use of Chinese in class, and assigning homework after class. However, they have shown very limited impact.

The language adjustment, aiming to enhancing students' understanding of the knowledge has done little to achieve the original goal for the reason that the abstract contents of theory-oriented course make students who haven't conducted any research project before hard to digest theoretical knowledge and apply it to the practical research project at the same time in a relatively short teaching period.

What's more, the questionnaires show that the reading tasks for students haven't displayed an effective influence on the stimulation of the students' behavioral participation. Lots of students have mentioned that while they were doing the reading, they don't have a real sense of the purposes and meaning of these tasks, thus, they're less likely to connect these reading materials with the theoretical knowledge and reinforce the understanding of it. However, objectively speaking, extra reading plays an important role for students to preview and review the class. Flipped classroom philosophy is recommended. When assigning the reading tasks, teachers could better inform students of the purpose and the questions to be discussed after the reading. Also, encouraging students to raise questions about the reading would be helpful to make the best of the reading tasks and have a good command of knowledge.

In the aspect of research topic selection, $38.75 \%$ of students believe that the teacher should just give students general domains such as a study of marketing discourse, but should not confine them to a specific topic predetermined. Therefore, the strategy of providing more concrete instructions in lectures is over-performed in the reform, which is believed will affect the student's enthusiasm and their homework completion quality. It is advised that the teacher performs as a learning assistant for the students when executing research projects.

\section{Suggestions and Implications}

This study indicates that the teaching reform of Research Methodology course has generated some positive effects on the students' learning whereas a few aspects haven't achieved satisfactory results. Some suggestions can be made based on the research results to facilitate the teaching and learning of Research Methodology and other courses of the same kind.

Firstly, the theory-oriented course should be postponed to the second year of university. The depth and difficulties of the course is one of the most significant contributory causes of the little students' participation in class. The difficulties in understanding are mostly due to the theory and abstract content that the course itself features. During the teaching reform, the teacher increases the tasks of previewing before class, increasing the frequency of the usage of Chinese in class, and assigning homework after class. However, they have shown very limited effects. The language adjustment, aiming to enhancing students' understanding of the knowledge has done little to achieve the original goal. Therefore, to adjust the curricular design is a sensible strategy.

Secondly, the teaching brings in flipped classroom philosophy. The course duration is limited, and the knowledge students can receive in one class is also limited. Extra reading and learning play an important play an important role for students to preview and review the class. Therefore, making use of modern informational technology, mainly aim at some difficult points, especially those take longer time. The teacher can form a discussion group on social networking application Wechat to answer students' questions online or even design micro-courses, to help the students to preview and review the lectures. This method can not only save time in class, but also enable the teacher to have more time arranging his teaching. What's more, it can enhance students' learning motivation and teacher-student interactivity.

Thirdly, the research method course is highly demanding practice that needs to be supplemented by professional guidance of teachers. Due to the theoretical characteristic of research method course, the increase in video display that did not combine with specific theoretical knowledge had played a limited role in helping students understand the theoretical knowledge of the course. The efficiency of simple group discussions was not high and lack teacher's guidance. So, it was hard to make a breakthrough. Objectively speaking, it is undeniable that adding video cases in teaching had made some contributions in this reform. However, in the process of video display, it should be explained with theoretical content to help students better understand the teaching details.

\section{Conclusion}

How to stimulate students' participation in curriculum behavior has always been the focus of English teachers' attention. The general theory-oriented course is the theoretical basis of the specialized course. Its teaching effect not only affects students' learning of this course, but also affects their further study. In view of such a fundamental status, this study takes Research Methodology course as an example to investigate the teaching approaches of all theory-oriented courses. This paper probes into how to stimulate students' participation in 
curriculum behavior through the reform of teaching methods, and then puts forward some countermeasures and suggestions for improving teaching methods and enhancing students' participation in curriculum behavior. Compared the differences between the improvement of their teaching methods and before, this study gets the results that after the teacher improves the teaching approaches, teaching difficulty of the class really is reduced and the actual condition of students is also improved. After analyzing the result of this survey, the author finds that by improvement of the teaching methods, the general theory courses of Business English major can optimize teaching results and improve students' satisfaction. In addition, the teaching reform needs to be carried out according to the needs of actual students in order to achieve the optimization of teaching results. Based on this, the author puts forward some suggestions on the reform of the general theory course for Business English majors. Of course, this study does not want the class teaching reform Business English major general theory be limited to a specific course or certain kinds of teaching methods, but expected to have more and more scholars pay close attention to the general theory courses of Business English major to enrich the existing literature.

There are still some limitations of this study. The data collected for comparative study is not comprehensive enough, which affects the real relationship between variables. Future studies can establish long enough research cycles when data is collected. Direct data such as student achievement after the reform were collected to achieve a more clear and effective comparison. The results obtained by this way make the existing research more convincing. At the same time, teachers and students can also be interviewed after the reform, which can more directly show the effectiveness of the teaching reform.

\section{Acknowledgement}

My study is supported by 2017 Guangdong Provincial Higher Vocational Education Entrepreneurship Teaching Steering Committee in the program titled "A Study on the Teaching Staff Construction for Business English Major Students in Higher Vocational College's Innovation and Entrepreneurship Education”(CYYB2017042).

\section{References}

Cao, Y. W., \& Zheng, C. L. (2017, July). Research on the Innovation of Business English Theory System from the Perspective of International Exchange. Journal of Beijing Institute of Graphic Communication, 25(07), 74-76.

Chu, H. Y., \& Cong, Q. H. (2017, September). How to Improve the Traditional Teaching Methods in Universities under Information Technology Environment. Journal of Lecture Room, 12(09), 153-154.

Jia, L. L. (2016, March). Using the Case Method in Business English Teaching. Journal of Lanzhou Institute of Education, 32(03), 123-124.

Jiang, H. Y. (2011, March). Task-based Teaching Approach in Business English Teaching. Journal of Shandong Radio and TV University, 12(03), 32-33, 39.

Li, G. (2014, November). Construction of the Practice Teaching System of Business English Major -A Case Study of Business English Major at CWNU. CAFLE, 160(06), 76-80.

Liu, F. G. (2015, January). On How to Fulfill Core Tasks of Business English Program's Cultivation Goals. Foreign Languages in China, 12(01), 19-25.

Wang, G. F., \& Zheng, H. S. (2011, June). A Study on Business English Teacher Competence in the Development of Business English. Foreign Language World, 147(06), 15-21.

Wang, L. N., \& Duan, J. (2010, April). The Case-Study Method in Business English Teaching. Foreign Language and Literature, 26(04), 96-100.

Xie, Q. S., \& Peng, L. (2009, January). Research on Business English Teaching Based on ESP Theory. Journal of Chongqing Radio and Television University, 21(01), 21-22, 25.

\section{Copyrights}

Copyright for this article is retained by the author(s), with first publication rights granted to the journal.

This is an open-access article distributed under the terms and conditions of the Creative Commons Attribution license (http://creativecommons.org/licenses/by/4.0/). 